\title{
Analysis of the Antecedents of Customer Loyalty of Telecommunication Industry in Ghana: The Case of Vodafone (Ghana)
}

\author{
Dr. Rosemond Boohene \\ Department of Management Studies, School of Business, University of Cape Coast, Ghana \\ Gloria K.Q. Agyapong \\ Department of Management Studies, School of Business, University of Cape Coast, Ghana
}

\begin{abstract}
The study investigated the determinants of customer loyalty in Vodafone (Ghana). The main variables of concern were service quality, customer satisfaction and image, even though other factors were also considered.

The study adapted the SERVQUAL model as the main framework for analyzing service quality. Multiple and logistic regression analyses were used to examine the relationships between service quality, customer satisfaction, image and customer loyalty. The results indicate that there is a positive relationship between service quality and customer loyalty. However, the results show a negative relationship between customer satisfaction and customer loyalty. The results of the findings suggest that Telecom management needs to emphasise service quality. Due to the fact that telecom firms do not provide tangible products, their service quality is usually assessed by measures of the service provider's relationship with customers. Thus, telecom service management should pay attention to staff skill possession and offering fast and efficient services.
\end{abstract}

Keywords: Service quality, Customer satisfaction, Image, Customer loyalty, Vodafone, SERVQUAL model.

\section{Introduction}

In today's globalised and borderless market, quality, productivity and satisfaction of customers pose a challenge for the survival and growth of all firms. These growth and survival demands are further deepened by the need to attract and retain loyal customers. Thus, the customer is the main focus for any successful business. Business success depends on a firm's understanding and meeting customers' needs and demands. In Ghana, service provision has always suffered a setback as service firms have always been criticised for providing poor quality of services. Due to poor service quality especially by most state-owned enterprises (SOEs), the government has had to privatise them in order to improve upon their service delivery. Others, both private and public have been made more competitive by introducing the appropriate strategies to enhance quality of service and customer satisfaction as well as developing quality control circles.

One important service in an economy is telecommunication. The telecommunication industry's role in an economy cannot be underemphasised. This is because it is the means through which all daily transactions and activities are undertaken. It aids decision making, organizing, influencing, activating, instructing, providing feedback, promoting interpersonal and business relationships as well as exchange of information. All social, economic, political, cultural, trade and commercial activities are undertaken using telecommunication. The nature of a country's telecommunication industry affects its pace of commercial and domestic activities. Due to the poor performance of many of these telecommunication firms, particularly in the developing countries, governments have had to intervene.

Indeed, the poor performance of these firms led to the deregulation of many of the telecom industries in many countries, of which Ghana is no exception (Frempong, 2002). This is because it is believed that state controlled telecom industry may impede innovation, efficiency and could stifle competition as the case was in Ghana prior to the Structural Adjustment Programme (SAP).

Prior to the deregulation of the telecom sector, few firms existed in the country to provide telephone, (mobile and fixed line), and internet services. Thus they charged exorbitant prices but provided restricted and shoddy services. Currently in the telecommunication subsector, five registered firms are operational. They include: MTN, Millicom Ghana Ltd., Vodafone (Ghana), Kasapa and Western Telecom (Westel now Zain). The sixth company, Globacom is in the process of acquiring its license from the National Communications Authority (NCA) - the body charged with the responsibility of registering, supervising and managing the country's telecom sector.

It is perceived that the incoming of those firms has been made possible by the reforms and adjustment programmes instituted in the country in the 1980s and 1990s. Nevertheless, the presence of these firms has introduced competition, efficiency and effectiveness in the telecom market in the country. Unlike the previous monopolistic, 
highly regulated telecom market, the presence of the new firms introduced service quality, appropriate and reasonable pricing and social responsibility. In effect, the deregulation policy of the telecom industry has aided in the current level of satisfaction enjoyed by its customers today. The deregulation, competition and advancement in information communications technology seems to be exerting pressure on managers in this industry to demonstrate customer-focused and continuous service improvement than before, as a way to ensuring customer satisfaction, brand supremacy and ultimately customer loyalty.

Customer loyalty has been found in the literature to be a competitive tool for many companies. This is even much more pronounced in today's highly globalised, industrialised and competitive markets. As has already been discussed in the background to the study, the growth and survival of companies depend on how loyal their customers are of which telecommunication is no exception.

Various studies have been carried out in the developed countries regarding customer loyalty (Ndubusi et al, 2007; Khatibi et al., 2002; Uncles et al 2003). Also, studies have been carried out regarding the relationship between service quality, customer satisfaction, image and customer loyalty in developed countries using the SERVQUAL model. However, only few studies have been carried out in this area in the developing world, especially in the telecom sub-sector. In Ghana, few researches have been carried out regarding customer loyalty and its antecedents but the research was conducted in the banking sector (Owusu-Frimpong, 1999) with none in the telecom sector. This study is being carried out to see if the factors that determine customer loyalty in the studies conducted in other areas will hold for the case of Ghana. Again, the telecom sub-sector in Ghana is neither perfectly competitive nor monopolistic but oligopolistic in nature. We therefore deem it appropriate to use the SERVQUAL model in determining the relationship between service quality, customer satisfaction, image and customer loyalty in a developing country context, more specifically, in a public sector telecom company.

The SERVQUAL model (Parasuraman, Ziethaml \& Berry, 1988) suggests that the differences between customers' expectations about the performance of a general class of service providers and their assessment of the actual performance of a specific firm in that class results in perceptions of quality. So that the first step in attaining customer loyalty is to determine the level of customer service through service quality assessment. Available literature seems to suggest that there is no consensus among researchers regarding the main factors underpinning customer loyalty (Khatibi, et al., 2002; Fornell et al 1996; Mittal \& Lassar 1998). Whereas Ruyter et al (1998), Boulding et al (1993) and Brady and Cronin (2001) found that high degree of service quality translates into loyalty, Aydin and Ozer (2005) and Cronin and Taylor (1992) are of a contrary opinion. They are of the view that service quality is a necessary but not sufficient condition to obtain customer loyalty.

Competition is supposed to bring about efficiency in the quality of service delivery in an economy. Inspite of the mushrooming of several telecom companies in Ghana, the quality of service delivered has not been up to scratch and yet, most of these providers have held on to their clients. What factors then may be accounting for the loyalty of their clients?

Service quality and corporate image were found to have a positive relationship with customer loyalty. However, customer satisfaction has a negative relationship with customers loyalty. This finding implies that among customers of Vodafone (Ghana), satisfaction is not a basis for loyalty. A reason accounting for this result may include the underdeveloped nature of the telecom sector. The next session reviews related literature, followed by data and methodology. The last two sections deal with results and discussion and conclusion and recommendations.

\section{Literature Review}

Loyalty as a concept has its root from the consumer behaviour theory and is something that consumers may exhibit to brands, services or activities. Often customer loyalty is used as opposed to brand loyalty to emphasise that loyalty is a feature of people, rather than something inherent in brands. Unfortunately, there is no universally agreed definition of loyalty (Jacoby \& Chestnut, 1978; Dick \& Basu, 1994; Oliver, 1999).

According to Beerli et al (2002), loyalty has been, and continues to be defined as repeat purchasing frequency or relative volume of same-brand purchasing. This, Oliver (1999) considered as an inadequate definition. He posits that most definitions of the concept in the literature suffer from the problem that they record what the consumer does, and none taps into the psychological meaning of loyalty. He thus defined loyalty as:

... a deeply held commitment to rebuy or repurchase a preferred product/service consistently in the future, thereby causing repetitive, same-brand or same brand-set purchasing, despite situational influences and marketing efforts having the potential to cause switching behaviour.

Jacoby and Kyner (1973) from a different perspective saw loyalty as the biased (i.e. non-random) behavioural response (i.e. purchase), expressed over time, by some decision-making unit, with respect to one or more alternative 
brands out of a set of such brands. This means that it is necessary to distinguish between exclusivity and loyalty and a function of psychological processes which involves the evaluation of different alternatives using specific criteria.

Thus in the view of Day (1969); Jacoby and Kyner (1973) and Berne (1997), loyalty is a concept that goes beyond mere repurchase behaviour as it presents two perspectives - behaviour and attitude, with all leading to commitment. Accordingly the combination of these two components enables us to distinguish two types of customer loyalty concepts:

(a) Loyalty based on inertia, where a brand is bought out of habit merely because this takes less effort and the consumer will not hesitate to switch to another brand if there is some convenient reason to do so. That is, the consumer is buying the same brand, not because of true brand loyalty, but because it is not worth the time and trouble to search for an alternative; and

(b) True brand loyalty, which is a form of repeat purchasing behaviour reflecting a conscious decision to continue, buying the same brand, must be accompanied by an underlying positive attitude and a high degree of commitment toward the brand.

Several factors have been identified to influence customer loyalty. As Beerli et al (2002) pointed out, there has been a growing interest in recent years in analysing the factors influencing customer loyalty especially in marketing of services. Among such variables that influence customer loyalty includes customer satisfaction and switching costs (Oliver, 1999; Berne', 1997; Bloemer \& Kasper, 1995; Anderson \& Sullivan, 1993; Boulding et al., 1993; Bloemer \& Lemmink, 1992)

In a review of customer defecting patterns, Reichheld et al. (2000) found $60-80 \%$ of customers who defect to a competitor said they were satisfied or very satisfied on the survey just prior to their defection. Also, Arasil et al (2005) showed that the switching cost factor directly affects loyalty, and has a moderator effect on both customer satisfaction and trust. Therefore, it plays a crucial role in winning customer loyalty. In short, it is a quasi moderator. However, switching cost was measured as a uni-dimensional factor. It was realised that switching costs contain psychological, financial and procedural sub-dimensions. Also, customer relationships and switching costs concurrently enhanced customer loyalty. Moreover, it has also been found that as customers' perceptions of switching costs increase, the longer they remain with a particular service supplier (Aydin \& Ozer, 2005; Patterson, 2004).

In addition, some other factors contributing to customer loyalty include customer relationships management strategies, corporate image, communication, and complaint handling. Zins (2001) posits that corporate image of the service provider is, along with service quality and customer satisfaction, a powerful and illustrative component for explaining future customer loyalty. Nguyen and Leblanc (2001) demonstrate that corporate image relates positively with customer loyalty in three sectors (telecommunication, retailing and education). The same relationship is demonstrated by Kristensen et al. (2000) for Danish postal services and by Juhl et al (2002) for the Danish food retailing sector. As pointed out above, corporate image stems from all of a consumer's consumption experiences, and service quality is a function of these consumption experiences. Hence, antecedents of customer loyalty and customer perception about service quality directly affect the perception of corporate image.

Service quality, customer satisfaction and image have been identified as the main predictors of customer loyalty (Khatibi et al. 2002; Nguyen and Leblanc, 2001; Gwyne et al. 1999, Woodside et al. 1989). The relationship between them have been examined and adopted for this research. This is depicted in the conceptual framework.

\subsection{Service Quality and Customer Loyalty}

Simon, Seigyoung and Karen (2005) identified that as customer-organization relationships deepen; consumers increase their expertise in the firm's product line and industry and develop increased switching costs. Technical service quality is hypothesized to be a more important determinant of customer loyalty than functional service quality as expertise increases. Both technical and functional service quality are hypothesized to have a reduced relationship with customer loyalty as perceived switching costs increase. Three-way interactions between the main effects of service quality, customer expertise, and perceived switching costs yield additional insight into the change in relative importance of technical and functional service quality in customers' decision to be loyal. They concluded that some relationship exist between service quality and customer loyalty. In addition, Wan-Jin, (2009) in examining the relationship between web-based service quality and customer loyalty found that service quality has a direct and positive effect on customer loyalty. The same relationship is demonstrated by Al-Rousan, and Badaruddin, (2010) in examining the relationship between service quality and customer loyalty in the Jordanian tourism industry.

The SERVQUAL model (Parasuraman, Ziethaml \& Berry, 1988) suggests that the differences between customers' expectations about the performance of a general class of service providers and their assessment of the actual 
performance of a specific firm in that class results in perceptions of quality. This is also widely known as gap analysis. Meanwhile, Aydin and Ozer (2005) showed that perceived service quality is necessary but not sufficient condition for customer loyalty.

Also, the SERVQUAL model has been mostly applied as a model to analyse service quality and consumer expectation. From the foregoing, it can be hypothesised that

$\mathbf{H}_{\mathbf{1}}$ : High level of service quality leads to a high level of customer loyalty

\subsection{Customer Satisfaction and Customer Loyalty}

Like customer loyalty, there is lack of consensus among researchers on the subject matter of customer satisfaction. This is because several researchers have looked at the concept from different perspectives. Rust and Oliver (1994) suggest that customer satisfaction or dissatisfaction - a "cognitive or affective reaction" - emerges as a response to a single or prolonged set of service encounters. In the words of Giese and Cote (2000), consumer satisfaction comprises three basic components including the type of response (cognitive, affective or conative); the centre of interest or the subject on which the response is focused; and the moment in time at which the evaluation is made. But Anderson and Fornell (1994) are of the view that the literature is not very clear about the distinction between quality and satisfaction. Satisfaction is a "post consumption" experience which compares perceived quality with expected quality, whereas service quality refers to a global evaluation of a firm's service delivery system (Anderson \& Fornell, 1994; Parasuraman et al., 1985).

According to Besterfield (1994); Barsky (1995) and Kanji and Moura (2002), customer satisfaction is a complex construct as it has been approached differently. In Levesque and McDougall (1996), satisfaction is conceptualized as an overall customer attitude towards a service provider. Also customer satisfaction has been described as an affective response, focused on product performance compared to some pre-purchase standard during or after consumption (Halstead et al., 1994). So Mano and Oliver (1993) established that satisfaction is an attitude or evaluative judgement varying along the hedonic continuum focused on the product, which is evaluated after consumption.

Whereas some researchers established a link between satisfaction and loyalty, others did not. For instance, Fornell (1992) was of the view that high customer satisfaction will result in increased loyalty for the firm and that customers will be less prone to overtures from competition. Similarly, Jones and Sasser (1995) found that an increase in customer satisfaction produces a stronger effect on loyalty among customers who are at the high end of the satisfaction scale. But the difficulty has always been how to define the scale of satisfaction. However, in Coyne (1989), it was concluded that the relationship between loyalty and customer satisfaction is weak when customer satisfaction is low, moderate when customer satisfaction is intermediate and strong when customer satisfaction is high. Thus, since different factors seem to affect the propensity to be loyal under the conditions of low and high satisfaction, it may be assumed that the form of the relationship between customer satisfaction and loyalty is different at different levels of satisfaction. Additionally, the relationship, between satisfaction and loyalty is neither simple nor linear and satisfied customers may defect (Jones \& Sasser, 1995). As a result, there are no simple solutions for turning loyalty into profits. If it were easy, however, everyone would already be doing it (Keiningham et al., 2007; Vázquez-Casielles, 2009). Despite the lack of consensus, however, they agreed there exist some relationship between customer satisfaction and customer loyalty. A third hypothesis can be inferred from the above discussion.

\section{$\mathbf{H}_{2}$ : High level of customer satisfaction will result in high level of customer loyalty for Vodafone (Ghana)}

\subsection{Corporate Image and Loyalty}

The study also considered other factors influencing customer loyalty such as switching cost, trust, relationship marketing strategies and complaint handling. These factors have been identified to reflect the corporate image of an organisation. Corporate image has also been described as the overall impression made on the minds of the public about a firm (Barich and Kotler, 1991). Nguyen and Leblanc (2001, p. 228) claim that corporate image is related to the physical and behavioural attributes of the firm, such as business name, architecture, variety of products/services, and the impression of quality communicated by each person interacting with the firm's clients. They concluded that corporate image relates positively with customer loyalty in three sectors including telecommunication, education and retailing. Although a customer may not have enough information about a firm, information obtained from different sources such as advertisements and word of mouth will influence the process of forming the corporate image. Fishbein and Ajzen (1975) argue that attitudes are functionally related to behavioural intentions, which predict behaviour. Also Rowley and Dawes (1999) posit that image (brand/corporate image) and expectations that 
users hold with respect to the nature and quality of their services affect customer loyalty. Consequently, corporate image as an attitude must affect behavioural intentions such as customer loyalty.

Anderson and Fornell, (1994), again in a business-to-business context, found effects of company reputation on trust. Their construct of company image includes (stability and firmly established, social contribution for society, concern with customers, reliability of what the firm says and does, innovative and forward looking). They argued for a possible relationship between image, not only between image and trust (that would then function as a mediator between image and loyalty), on the obvious grounds that trust is to some extent built on reputation, but also for possible direct effects of image on loyalty. That is, consumers may be loyal to a firm or brand because it is viewed as having a positive image among other consumers; particularly in credence goods and this alone may provoke some amount of unwillingness to switch (Wang, 2010) . Corporate image has a significant positive impact on customer loyalty (Andreassen, 1999). A good corporate image can compensate for a bad or mediocre complaint resolution. Customers will balance the complaint resolution experience with previous encounters, that is customers may consider the initial incident as irregular and not representative for the company. In this respect corporate image functions as an aggregated expectation formed through previous encounters or external sources. From the above discussion, it can be hypothesized that

\section{$\mathbf{H}_{3}$ : Good corporate image leads to high customer loyalty}

\subsection{Service Quality, Customer Satisfaction and Customer Loyalty}

Evidence from the service marketing literature indicates that these concepts have either been severally defined and/or used interchangeably. For the purpose of this study, service quality has been defined as the difference between customer expectations and perceptions of service delivered (Gronroos, 1984; Parasuraman et al., 1988, 1991). Customer loyalty has been defined as an attitude or behaviour of customer to commit to the firm's product, buy or making frequent purchase, repurchase and product recommendation; engages in brand defense as well as establishing a long term relationship with the firm. Customer satisfaction is defined as an overall evaluation based on the total purchase and consumption experience focused on the perceived service performance compared with prepurchase expectations over time. Also customer satisfaction is a measure that suggests meeting minimum or basic requirements. Inherently, it falls short of truly helping an organization identify customer needs and expectations, what to do with them, and why. Usually, those customers proclaiming to be "extremely or very satisfied" may be the least profitable customers in terms of revenue and product usage indicators to a firm (Tutton, 2007). With the role of the customer changing gradually (Prahalad \&Ramaswamy, 2000), customer perceived service quality has been given more and more attention for its specific contribution to the competitiveness of business and there have been a variety of studies on different issues concerning service quality over the last several years. These researchers believed that measuring service quality as disconfirmation (the difference between perceptions and expectations) is valid and allows service providers to identify several gaps in the service provided. However, most of these studies have found a poor fit for the disconfirmation model.

The effects of service quality on consumer decision-making appear to be largely indirect and mediated by value and satisfaction (Brady \& Cronin, 2001). A review of literature reveals that the terms quality and satisfaction are quite often used interchangeably. While both concepts are related and appear to be merging, there are still gaps in understanding the two constructs, their relationship to each other and their antecedents and consequences (Gwynne et al., 1999). A distinction has often been made between the two constructs. According to Cronin and Taylor (1992), this distinction is important to both managers and researchers alike, because service providers need to know whether their objective should be to have consumers who are satisfied with their performance or to deliver the maximum level of perceived service quality.

Oliver (1997) takes the view that satisfaction is the 'emotional reaction following a disconfirmation experience'. Getty and Thompson (1994) defined satisfaction as a 'summary psychological state experienced by the consumer when confirmed or disconfirmed expectations exist with respect to a specific service transaction or experience'. Rust and Oliver (1994) suggested that customer satisfaction or dissatisfaction - a 'cognitive or affective reaction' emerges as a response to a single or prolonged set of service encounters. Satisfaction is a 'post-consumption' experience which compares perceived quality with expected quality, whereas service quality refers to global evaluation of a firm's service delivery system (Parasuraman et al, 1985; Anderson \& Fornell, 1994). Perceived quality, on the other hand may be viewed as a global attitudinal judgement associated with the superiority of the service experience over time (Getty \&Thompson 1994). As such, it is dynamic in nature and less transaction specific (Parasuraman et al, 1988).

Ruyter et al (1998) contends that the concept of loyalty and satisfaction are closely related concepts. They said that conceptually, the idiosyncratic nature of each service setting limits the generalisability of previous research findings 
with regard to behavioural intentions, especially as most of the studies linking service quality, satisfaction and behavioural intentions have been conducted in one specific service setting. Therefore, they proposed a cross-sectional perspective to gain further insight into the development of service loyalty. Jones and Sasser (1995) concluded that the relationship between customer evaluations and loyalty across industries is "neither linear nor simple". It has been suggested that the degree of switching costs may have an influence on customer loyalty in a given industry (Anderson \& Fornell, 1994; Dick \& Basu, 1994; Fornell, 1992; Gremler \& Brown, 1996). The fourth hypothesis can be deduced from the discussion and thus is

$\mathbf{H}_{4}$ : Service quality exerts a strong influence on customer satisfaction which translates into high customer loyalty.

\subsection{Conceptual Framework Developed for the Study}

The framework for the study was adopted and modified from the empirical study by Beerli et al (2002) depicted in figure 1. The figure illustrates the relationship among service quality, customer satisfaction, image and customer loyalty.

\section{=INSERT FIGURE 1 HERE $=$}

The framework indicates that perceived quality is considered an antecedent of customer satisfaction (Woodside et al., 1989; Reidenbach \& Sandifer-Smallwood, 1990; Cronin \& Taylor, 1992; Fornell, 1992; Anderson \& Sullivan, 1993; Gotlieb et al., 1994; Spreng \& Mackoy, 1996). It indicates that the quality of service measured by the SERVQUAL variables may lead to customer loyalty or lead to customer satisfaction that can translate into loyalty. A vast number of specific constructs have been used in conceptual discussions and empirical examinations of customer loyalty, yet they seem to have at least one thing in common (at a very high level of aggregation): they refer to the customer's relationship over time toward one specific object (a vendor, a brand, a service supplier, etc.) (Soderlund, 2005).

\section{Data and Methodology}

The target population of the study comprised 7,621 clients of Vodafone (Ghana) in the Cape Coast Metropolitan area. This was obtained from the database of Vodafone (Ghana). The company was chosen because as of the time data was collected, it was the state-owned majority shareholder. Also, customers were complaining about their services. This was made known when NCA gave a directive for GT and MTN to halt selling their SIMcards and improve the quality of their services. The branch in Cape Coast was chosen due to time and financial constraints and also to be able to control internal validity. Currently, the company has been privatised with Vodafone holding 70 per cent shares.

To ensure that an adequate number of responses were received, the sample size was determined using Hair et al's (2002) sample size determination formula. The researcher used simple random sampling to collect the data. This sampling technique was chosen relative to the others because it is easily understood, the sample results may be projected to the target population and there is no (human) interference in the selection of the sample. However, using this sampling technique, it is often difficult to construct a sampling frame that will permit a simple random sample to be drawn.

The main instrument for data collection was the questionnaire. The questionnaire was developed based on the stated hypothesis and also based on the SERVQUAL model. Both open-ended and closed-ended questions were used. The questions were on a 7-point Likert scale. The scores were coded 7 for strongly agree or strongly satisfied, 6 for moderately agree or moderately satisfied, 5 slightly agree or satisfied, 4 for neutral or indifferent, 3 for somehow disagree or slightly dissatisfied, 2 for disagree or moderately dissatisfied and 1 for strongly disagree or highly dissatisfied.

\subsection{Measurement of Variables}

Service quality was measured by using the variables suggested in the SERVQUAL model (Parasuraman, Zeithmal \& Berry, 1988, Ndubisi, Chan, \& Chukwunonso, 2004). In applying the SERVQUAL model, 21 statements were used to measure service quality across these elements, based a seven point Likert scale. The factors in the model were measured as follows: tangibles, reliability, responsiveness, competence, courtesy, security, access, communication, and understanding the customer.

The performance ratings of cellular phones reported in consumer reports (1998) were used by Lee et al (2001) as a basis for measuring consumer satisfaction where the main factors considered were opinions of consumers regarding pricing plan, core services (coverage of the calling area and the clarity of sound) and value-added services (precision of billing services and easy access to provider). Customer satisfaction is thus measured by using customer complaint rate, negative affect/emotions, reluctant to switch, customer service, first choice and search motivation 
Measurement of corporate image was done by modifying and using the measures in Aydin and Ozer (2005). Image is measured by using switching cost, trust, relationship marketing strategies and complaint handling.

To measure customer loyalty, a subset of the original measures in Narayandas (2005) and Lee et al (2001) were modified and used such as repurchase intent, resistance to switch to competitors' product that is superior to the preferred one, and willingness to recommend preferred products to friends and associates.

Five hundred and twenty (520) questionnaires were administered at the company's main office and retail outlets where the Vodafone's products are sold in the Cape Coast Metropolitan Area. On the whole, out of the 520 respondents visited, about 460 provided completed questionnaires; the remaining questionnaires were given back uncompleted. This resulted in 88 per cent retrieval.

The results were analyzed to find the strength of the cause and effect relationships using multiple regression (see Malhotra, 2007) and binary choice model. Arysad (2005) argues that since the datasets are not normally distributed, ordinary least square (OLS) model will lead to inefficient parameters estimates, because of heteroscedasticity problem, hence the two models to avoid paying for the penalty of possible inefficient parameter. Arysad (2005) suggests the use of binomial or binary choice model - such as probit and logit model - to overcome the problems because it uses a dummy variable instead of a continuous variable. The probit and logit models usually give similar results and it is difficult to distinguish them statistically, since the cumulative normal distribution of probit model and the logistic distribution are very close to each other. However, the assumption underlying the distribution is normal and makes probit analysis somewhat more restricted than logit analysis. The logit model can be used without any change even with unequal sample sizes. For these reasons, this study employs the logistic model as additional tool to correct the classical assumptions of ordinary least square which may affect the interpretation to results.

\section{Results and Discussion}

The results of the hypothesis are discussed in this section.

\section{$=$ INSERT TABLE 1 HERE =}

The significance of the estimated coefficients of the variables is based on Wald's statistic. From Table 1, service quality is significant in explaining customer loyalty. The positive sign of the coefficient $(B=1.760)$ indicates that there is a positive relationship between service quality and customer loyalty. So quality service for instance will result in higher loyalty towards the brand of service. The odds ratio given as $\operatorname{Exp}(B)=5.87$, indicates that the model predicts a probability that based on the current level of service quality, the customer will be loyal. Thus, a manager seeking to increase brand loyalty should focus on improving quality of service.

$=$ INSERT TABLE 2 HERE =

To test for the significance of the estimated coefficients, the Wald's statistic was again used. From Table 2, customer satisfaction is observed to be significant $(p<0.005)$ in explaining customer loyalty even though there is an inverse relationship between the two. The negative sign for the coefficient indicates that as customer satisfaction decreases, customer loyalty towards the brand still increases and vice versa. The odds ratio given as $\operatorname{Exp}(\mathrm{B})=.215$, indicates that the model predicts a probability that based on the current level of satisfaction; the customer will still be loyal. This finding implies that among customers of Vodafone (Ghana), satisfaction is not a basis for loyalty. Some reasons accounting for this result may include the underdeveloped nature of the telecom sector. Also, the other competitive firms have challenges causing dissatisfaction but people are still loyal. So customers switching is not necessarily because they are satisfied or not. Again, the other networks may not be providing superior services but average services hence customers feel better off staying with their current telecom providers. As has already been alluded to, managers of these firms should focus on improving the quality of service as an effective means to increase customer loyalty.

$=$ INSERT TABLE 3 HERE $=$

The results from Table 3 shows that corporate image is observed to be significant in explaining customer loyalty. The positive sign for the coefficient indicates that as corporate image increases, customer loyalty towards the brand increases. Attitudes are functionally related to behavioural intentions, which predict behaviour. Consequently, corporate image as an attitude must affect behavioural intentions such as customer loyalty. The odds ratio given by Exp $(B)=3.135$, indicates that the model predicts a probability of image influencing the loyalty of customers of Ghana Telecom. It implies that corporate image is necessary in influencing loyalty.

$=$ INSERT TABLE 4 HERE $=$

The results indicate that there is statistically positive relationship between service quality and customer loyalty. This is indicated by the positive coefficient (.087), significant at 0.05 level shown in Table 4 . However, it was found that 
there is statistically negative relationship between customer loyalty and customer satisfaction. The results also show a positive relationship between customer loyalty and corporate image. This indicates that there is a strong direct positive relationship between overall customer loyalty and corporate image.

Furthermore, the regression model shows that 64.2 per cent of the observed variability in customer loyalty $\left(R^{2}=.642\right)$ is explained by the independent variables (service quality, customer satisfaction and image) under study. In addition, the results of analysis of variance (ANOVA) with $\mathrm{F}=272.862$ indicate that the model has a high predictive power. Thus, the result indicates that the three independent variables are significant in analysing customer loyalty in Vodafone (Ghana). This hypothesis predicts that service quality influences customer satisfaction which eventually translates into customer loyalty. From the table, the overall predictive power of the model is significant with an $\mathrm{R}^{2}$ $=.642$. In effect, the joint significance of service quality and customer satisfaction (with corporate image as controlling variable) predicting customer loyalty is better than the individual variables. However, much as customer satisfaction was expected to be a major determinant of customer satisfaction, the results showed otherwise. Thus, service quality can translate into customer satisfaction but it cannot translate into customer loyalty through customer satisfaction.

\section{Conclusions and Recommendations}

These findings imply that providing quality service is a critical for customers to stay with a brand or a telecommunication provider. There is a positive relationship between service quality and customer loyalty. This means building customer loyalty depends to a large extent on ensuring that the firm maintains high service quality standards. Putting in place quality mechanisms will drive customer loyalty to a greater height

Putting in place quality mechanisms will drive customer loyalty to a greater height. Hence the first hypothesis was substantiated. These quality measures as have been suggested in most empirical works are contained in the SERVQUAL framework made up of variables such as courtesy, tangibility, reliability, responsiveness, competence, communication, access, security and understandability among others. It can be concluded that for customers to be loyal, telecom firms must provide appealing sales points, wide coverage, neat, comfortable and convenient office locations as well as being responsive to their requests.

However a high level of customer satisfaction may not necessarily result in high customer loyalty. Therefore focusing a great deal on satisfaction may not drive up customer loyalty as it can bring about possible neglect of some important service quality aspects that can bring about a decrease in customer loyalty. . However, focusing on customer satisfaction, may be necessary as it might enable the firm to cater for some important aspects of the services (e.g. switching cost, complaint handling) that may not be included in the service quality model.

There was a strong positive relationship between corporate image and customer loyalty. This means that falling corporate image will push down the level of customer loyalty. It can be concluded that corporate image is of significance for the firm's customers to stay with it.

The overall predictive power of the service quality model used in predicting customer loyalty is greater when customer satisfaction is used as a mediator than when it is used alone. In effect, the joint significance of service quality and customer satisfaction (with corporate image as controlling variable) for predicting customer loyalty is better than the individual variables. However, much as customer satisfaction was expected to be a major determinant of customer, the results showed otherwise. It can thus be concluded that service quality can translate into customer satisfaction but it cannot translate into customer loyalty through customer satisfaction.

For managers, these findings have important implications with regard to brand building strategies. Key to profitability is customer loyalty. The study has documented that quality of service is the most significant factor in obtaining customer loyalty. Therefore Telecom management needs to emphasize service quality. Due to the fact that telecom firms do not provide tangible products, their service quality is usually assessed by measures of the service-provider's relationship with customers. Thus, telecom service management should pay attention to staff skill possession, knowledge, attention to customers and their needs, offering fast and efficient services and general attitude to customer services.

Other issues for gaining customer loyalty for telecom services include confidentiality in transactions, trustworthiness of staff, availability of customer care centres on weekends, extension of working hours, and provision of security for customers' transactions. Invariably, there is need for the management of telecom firms to intermittently train their workers on relationship marketing skills. Such training would build a customer-oriented climate in which contact staff can deliver service efficiently and effectively, acknowledging that acquiring and retaining customers is the very essence of marketing. 
Finally, the behaviour of Vodafone's customers is such that they still remain loyal even when they are not satisfied with the services they receive. If the company should further improve upon its services, their customers are likely to stay with them for a very long time - possibly strengthen their relationship with the company.

\section{References}

Al-Rousan, M. R. \& Badaruddin, M. (2010) Customer loyalty and the impacts of service quality: The case of five star hotels in Jordan. International Journal of Business, Economics, Finance and Management Sciences, 2(3)

Anderson, E \& Sullivan, M.W. (1993). The antecedents and consequences of customer satisfaction for firms. Marketing Science, 12 (2), 125-43

Anderson, E.W. \& Fornell, C. (1994). Customer satisfaction, market share and profitability: Findings from Sweden. Journal of Marketing, 58(3), 53.

Andreassen, W.T. (1999). What drives customer loyalty with complaint resolution? Journal of Service Research, 1 (4)

Arasil, O. (2005). Customer loyalty and the effect of switching costs as a moderator variable a case in the Turkish mobile phone market. Marketing Intelligence \& Planning, 23(1), 89-103, Emerald Group Publishing Limited, 0263-4503.

Arsyad L. (2005) An assessment of performance and sustainability of Microfinance Institutions: A case study of Village credit institutions in Gianyar, Bali, Indonesia, unpublished PhD thesis, Flinders University, Australia

Aydin, S. \& Ozer, G. (2005). The analysis of antecedents of customer loyalty in the turkish mobile telecommunication market. European Journal of Marketing, 39 (7/8), 910-925.

Barich, H. \& Kotler, P. (1991). A framework for marketing image management. Sloan Management Review, 32 (2), 94-104.

Barsky, J. (1995). World-class customer satisfaction. Burr Ridge, IL: Irwin Professional

Beerli, A., Martin, D.J. \& Quintana, A. (2002). A model of customer loyalty in the retail banking market. European Journal of Marketing, 38(1), 253-275.

Berne', C. (1997). Modelizacio'n de la poscompra: Satisfaccio'n y lealtad. In Mu'gica Grijalva, J.M. \& Ruiz de Maya, S. (Eds), El Comportamiento del Consumidor,(pp163-80) Cap. 5, Ariel Economı'a, Barcelona.

Besterfield, D.H. (1994). Quality Control. Englewood Cliffs, NJ: Prentice-Hall,

Bloemer, J.M. \& Kasper, H. (1995). Brand loyalty and brand satisfaction: The case of buying audio cassettes anew in the Netherlands. In Proceeding of the 22nd European Academy Conference, Barcelona.

Bloemer, J.M. \& Lemmink, J.G. (1992). The importance of customer satisfaction in explaining brand and dealer loyalty. Journal of Marketing Management, 8, 351-64.

Boulding, W., Kalra, A., Staelin, R. \& Zeithaml, V. A. (1993, February). A dynamic process model of service quality from expectations to behavioural intentions. Journal of Marketing Research, 30, 7-27

Brady, M. K., \& Cronin, J. J. (2001, July). Some new thoughts on conceptualising perceived service quality: A hierarchical approach. Journal of Marketing, 65.

Consumer Reports (1998). Buying Guide Issue. September, Consumers Union of United States, New York

Coyne, K. (1989). Beyond service fads - meaningful strategies for the real world. Sloan Management Review, 30, 69-76.

Cronin, J. J. Jr \& Taylor, S. A. (1992). Measuring service quality: A re-examination and extension. Journal of Marketing, 56, 405-20

Day, G.S. (1969). A two-dimensional concept of brand loyalty. Journal of Advertising Research, 9, 29-35.

Dick, A. \& Basu, K. (1994). Customer loyalty: Toward an integrated conceptual framework. Journal of Marketing Science. 22 (2), 99-113

Fishbein, M. \& Ajzen, I. (1975). Belief, attitude, intention, and behavior: An introduction to theory and research. Reading, MA: Addison-Wesley

Fornell, C. (1992). A national customer satisfaction barometer: The Swedish experience. Journal of Marketing, 56, 6-21 
Fornell, C., Johnson, M.D., Anderson, E.W., Cha, J. \& Bryang, B.E. (1996). The American customer satisfaction index: Nature, purpose, and finding. Journal of Marketing, 60, 7-18

Frempong, G. (2002). Telecommunication Reforms - Ghana's Experience. Discussion Paper, Technical University of Denmark

Getty, J.M. \& Thompson, K.N. (1994). The relationship between quality, satisfaction and recommending behaviour in lodging decision. Journal of Hospitality and Leisure Marketing, 2(3), 3-22

Giese, J. L. \& Cote, J. A. (2000). Defining consumer satisfaction. Academy of Marketing Science Review (on line).

Gotlied, J.B., Dhurv, G. \& Brown S.W. (1994). Consumer satisfaction and perceived quality: complementary or divergent constructs? Journal of Applied Psychology, 79(6), 875-885.

Gremler, D.D. \& Brown, S.W. (1996). The loyalty ripple effect: Appreciating the full value of customers. International Journal of Service Industry Management, 10(3), 271-91.

Gronroos, C. (1984). A service quality model and its marketing implications. European Journal of Marketing, 18, 36-44.

Gwyne, A., Ennew, C. \& Devlin, J. (1999). Service quality and customer satisfaction: $A$ longitudinal analysis. Proceedings of the $28^{\text {th }}$ European Marketing Academy Conference, Humboldt Univeristy, Berlin, 25.

Hair, J.F. Jnr., Bush, R.P \& Ortinau D.J. (2002). Marketing research: A practical approach for the new millennium. New York: Irwin McGraw-Hill

Halstead, D., Hartman, D. \& Schmidt, S.L. (1994). Multisource effects on the satisfaction formation process. Journal of the Academy of Marketing Science, 22, 114-29.

Jacoby, J. \& Chestnut, R. (1978). Brand loyalty: Measurement and management. New York NY: John Wiley \& Sons.

Jacoby, J. \& Kyner, D.B. (1973). Brand loyalty vs. repeat purchasing behaviours. Journal of Marketing Research, 10, 1-19.

Jayaraman, M. \& Vong, O. F. (2008). An examination of the relationship between service quality and customer satisfaction in a training organization. Unitar E-Journal 4(2)

Jones, T. \& Sasser, W. (1995). Why satisfied customers defect. Harvard Business Review. 73(6), 88-99

Juhl, H.J., Kristensen, K. \& Ostergaard, P. (2002). Consumer satisfaction in European food retailing. Journal of Retailing and Consumer Services, 9(6), 27-34.

Kanji, G. \& Moura, P. (2002). Kanji’s business scorecard. Total Quality Management, 13(1), 13-27.

Keiningham, T.L., Cooil, B., Andreassen, T.W. \& Aksoy, L. (2007). A longitudinal examination of 'net promoter' on firm revenue growth. Journal of Marketing (forthcoming).

Khatibi, A.A., Ismail, H. \& Thyagarajan, V. (2002). What drives customer loyalty: An analysis from the telecommunications industry. Journal of Targeting, Measurement and Analysis for Marketing, 11(1), 34-44, Henry Stewart Publications 0967-3237

Lee, J., Lee, J. \& Feick, L. (2001). The impact of switching costs on the customer satisfaction-loyalty link: Mobile phone service in France. Journal of Services Marketing, 15(1), 35-48.

Levesque, T. \& McDougall, G. (1996). Determinants of customer satisfaction in retail banking. International Journal of Bank Marketing, 14(7), 12-20.

Mano, H. \& Oliver, R.L. (1993). Assessing the dimensionality and structure of the consumption experience: evaluation, feeling, and satisfaction. Journal of Consumer Research, 20, 451-66.

Mittal, B. \& Lassar, W.M. (1998). Why do customers switch? The dynamics of satisfaction versus loyalty. Journal of Services Marketing, 12(3), 177-94.

Narayandas, D. (2005). Building loyalty in business markets. Harvard Business Review, 131-40.

Ndubisi O.N., Wah, K.C. \& Ndubisi C.G. (2007). Supplier-customer relationship management and customer loyalty: the banking industry perspective. Journal of Enterprise Information Management, 20(2), 222-236

Ndubisi, N.O., Chan, K.W. \& Chukwunonso, N.C. (2004). Evaluating relationship marketing strategies and customer loyalty. International Logistics Congress Proceeding, 11, Izmir. 
Nguyen, N. \& Leblanc, G. (2001). Corporate image and corporate reputation in customers'retention decisions in services. Journal of Retailing and Consumer Services, 8, 227-36.

Oliver, R.L. (1999). Whence consumer loyalty. Journal of Marketing. 63, 33-44

Owusu-Frimpong, N. (1999). Patronage behaviour of Ghanaian bank customers. International Journal of Bank Marketing, 17(7), 335-342

Parasuraman, A., Zeithaml V. A. \& Berry, L. L. (1991). Refinement and reassessment of the SERVQUAL scale. Journal of Retailing, 67 (4), 420-450.

Parasuraman, A., Ziethaml, V.A. \& Berry, L.L. (1985). A conceptual model of service quality and its implications for further research. Journal of Marketing. 49, 41-50

Parasuraman, A., Ziethaml, V.A. \& Berry, L.L. (1988). SERVQUAL: A multiple-item scale for measuring consumer perceptions of service quality. Journal of Retailing. 64(1), 12-40

Patterson, P.G. (2004). A contingency model of behavioural intentions in a service context. European Journal of Marketing, 38(9-10), 1304-15.

Prahalad, C.K. \& Ramaswamy, V. (2000). Co-opting customer competence. Harvard Business Review, 78(1), 79-87.

Reichheld, F., Markey, R. \& Hopton, C. (2000). The loyalty effect - the relationship between loyalty and profits. European Business Journal, 12(3), 134-9.

Reidenbach, R.E. \& Sandifer-Smallwood, B. (1990). Exploring perceptions of hospital operations by a modified SERVQUAL approach. Journal of Health Care Marketing, 10, 47-55.

Rowley, J. \& Dawes, J. (1999). Customer loyalty - a relevant concept for libraries? Library Management, 20(6), 345-51

Rust, R.T. \& Oliver, R.L. (1994). Service quality: insights and managerial implications from the frontier. In Rust, R.T. \& Oliver, R.L. (Eds), Service quality: New directions in theory and practice, (241-68).

Ruyter, K.., Wetzels, M. \& Bloemer, J.M. (1998). On the relationship between perceived service quality, service loyalty and switching costs. International Journal of Service Industry Management, 9(5), 436-453

Simon, J. B., Seigyoung, A., \& Karen, S. (2005). Customer relationship dynamics: service quality and customer loyalty in the context of varying levels of customer expertise and switching costs. Journal of the Academy of Marketing Science, 33(2), 169-183

Söderlund, M. (2005). Customer satisfaction and its consequences on customer behaviour revisited. International Journal of Service Industries Management, 9(2), 169-88

Spreng, R.A. \& Mackoy, R.D. (1996). An empirical examination of a model of perceived service quality and satisfaction. Journal of Retailing, 72(2), 201-14.

Tutton, G. (2007). Customer satisfaction versus loyalty. Retrieved from the Wise Marketer, http://www.thewisemarketer.co./features/read.asp?id=110

Uncles, M., Dowling, G. \& Hammond, K. (2003). Customer loyalty and customer loyalty programs. Journal of Consumer Marketing, 20(4), 294-316

Vázquez-Casielles, R. (2009) Customer satisfaction and switching barriers: Effects on repurchase intentions, positive recommendations, and price tolerance. Journal of Applied Social Psychology 39(10)

Wang, C.Y. (2010) Service quality, perceived value, corporate image, and customer loyalty in the context of varying levels of switching costs. Psychology and Marketing, 27(3)

Wan-Jin, L. (2009). The relationship between web-based service quality and customer loyalty. Nova Southeastern University

Woodside, A.G., Frey, L.L. \& Daly, R.T. (1989). Linking service quality, customer satisfaction and behavioural intention. Journal of Health Care Marketing, 19, 5-17.

Zins, A.H. (2001). Relative attitudes and commitment in customer loyalty models. International Journal of Service Industry Management, 12(3), 269-94. 
Table 1. Service Quality and Customer Loyalty

\begin{tabular}{llllllll}
\hline \multicolumn{2}{l}{ Independent Variable } & B & S.E & Wald & d.f. & Sig. & Exp(B) \\
\hline Step $1^{\text {a }} \quad$ Service Quality & 1.760 & .213 & 48.269 & 1 & .000 & 5.812 \\
& Constant & .384 & .132 & 8.440 & 1 & .004 & 1.069 \\
$\mathrm{~N}=460$ & & & & & & \\
-2 Loglikelihood $=344.239^{\mathrm{a}}$ & & & & & & \\
Cox \& Snell R Square $=.453$ & & & & & & \\
Nagelkerke R Square $=.507$ & & & & & & \\
\hline
\end{tabular}

a. Variable(s) entered on step 1: Service Quality

b. Estimation terminated at iteration number 4 because parameter estimates changed by less than .001

Table 2. Customer Satisfaction and Customer Loyalty

\begin{tabular}{|c|c|c|c|c|c|c|c|}
\hline \multicolumn{2}{|c|}{ Independent Variable } & \multirow{2}{*}{$\begin{array}{l}\mathrm{B} \\
-1.537\end{array}$} & \multirow{2}{*}{$\begin{array}{l}\text { S.E } \\
.206\end{array}$} & \multirow{2}{*}{$\frac{\text { Wald }}{45.724}$} & \multirow{2}{*}{$\begin{array}{l}\text { d.f. } \\
1\end{array}$} & \multirow{2}{*}{$\begin{array}{l}\text { Sig. } \\
.000\end{array}$} & \multirow{2}{*}{$\begin{array}{l}\operatorname{Exp}(\mathrm{B}) \\
.215\end{array}$} \\
\hline Step $1^{\mathrm{a}}$ & Customer Satisfaction & & & & & & \\
\hline & Constant & .326 & .134 & 4.926 & 1 & .015 & 1.385 \\
\hline \multicolumn{8}{|l|}{$N=460$} \\
\hline \multicolumn{8}{|c|}{-2 Loglikelihood $=320.288^{\mathrm{a}}$} \\
\hline \multicolumn{8}{|c|}{ Cox \& Snell R Square $=.423$} \\
\hline Nagelke & quare $=.466$ & & & & & & \\
\hline
\end{tabular}

a. Variable(s) entered on step 1: Customer Satisfaction

b. Estimation terminated at iteration number 4 because parameter estimates changed by less than .001

Table 3. Corporate image and Customer Loyalty

\begin{tabular}{|c|c|c|c|c|c|c|c|}
\hline \multicolumn{2}{|c|}{ Independent Variable } & B & S.E & Wald & d.f. & Sig. & $\operatorname{Exp}(B)$ \\
\hline \multirow[t]{2}{*}{ Step $1^{\mathrm{a}}$} & Corporate Image & 1.143 & .208 & 30.311 & 1 & .000 & 3.135 \\
\hline & Constant & -1.099 & .168 & 42.545 & 1 & .000 & .333 \\
\hline \multicolumn{8}{|l|}{$N=460$} \\
\hline \multicolumn{8}{|c|}{-2 Loglikelihood $=288.378^{\mathrm{a}}$} \\
\hline \multicolumn{8}{|c|}{ Cox \& Snell R Square $=.468$} \\
\hline \multicolumn{8}{|c|}{ Nagelkerke R Square $=.492$} \\
\hline
\end{tabular}

a. Variable(s) entered on step 1: Corporate Image

Estimation terminated at iteration number 4 because parameter estimates changed by less than .001

Table 4. Relationship between Service Quality, Customer Satisfaction, Image and Customer Loyalty

\begin{tabular}{llc}
\hline Variables & Coefficients & t-values \\
\hline Constant & -.388 & -1.161 \\
Total Service Quality & .087 & $8.941^{*}$ \\
Customer Satisfaction & -.075 & $-7.952^{*}$ \\
Corporate Image & .133 & $7.609^{*}$ \\
F-Statistics $=(272.862,000)$ & & \\
R-Square $=.642$ & & \\
Adj. R-Square $=640$ & & \\
\hline
\end{tabular}

a. Predictors: constant, Total Service Quality, Customer Satisfaction, Image

b. Dependent Variable: Customer Loyalty

c. Variables are significant at 0.05 level

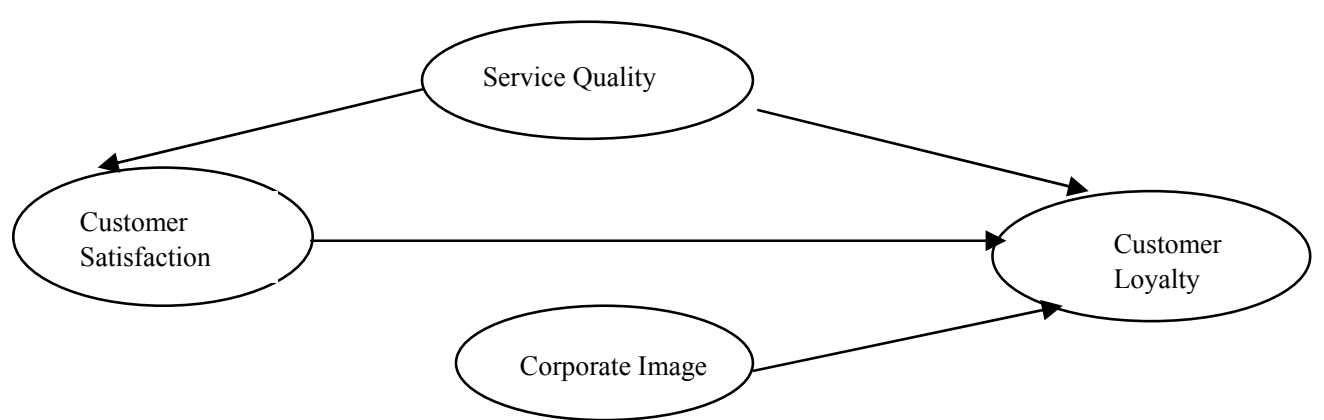

Source: Adopted from Beerli, Martin and Quintana (2002)

Figure 1. Relationship among Service Quality, Customer Satisfaction Image and Customer Loyalty 